\title{
Post of Lampasas: Forgotten Reconstruction Era U.S. Army Post (1867-1870)
}

Richard S. Jones

USAG Fort Hood, DPW-ENV

Follow this and additional works at: https://scholarworks.sfasu.edu/ita

Part of the American Material Culture Commons, Archaeological Anthropology Commons, Environmental Studies Commons, Other American Studies Commons, Other Arts and Humanities Commons, Other History of Art, Architecture, and Archaeology Commons, and the United States History Commons

Tell us how this article helped you.

This Article is brought to you for free and open access by the Center for Regional Heritage Research at SFA ScholarWorks. It has been accepted for inclusion in Index of Texas Archaeology: Open Access Gray Literature from the Lone Star State by an authorized editor of SFA ScholarWorks. For more information, please contact cdsscholarworks@sfasu.edu. 


\section{Post of Lampasas: Forgotten Reconstruction Era U.S. Army Post (1867-1870)}

\section{Licensing Statement}

Reproduction, posting, transmission, or other distribution or use of the Journal volume, individual article or any portion of the material therein, in any medium, is permitted strictly for personal, non-commercial purposes via a personal-use exemption under a Creative Commons license granted by JTAH.org, Inc. This license exemption requires, as a condition of its granted permission, proper credit be attributed to JTAH.org as copyright holder (e.g., Journal of Texas Archeology and History.org (C 2014). No part of this publication may be reproduced, posted, transmitted, or otherwise utilized or distributed in any form by any means or method for commercial purposes without the express written consent of the Publisher.

Inquiries should be addressed to JTAH Publisher, Suite 307, Box 361, 5114 Balcones Woods Drive, Austin, Texas, 78759.

The Journal of Texas Archeology and History.org is an organization dedicated to furthering research, education and public outreach in the fields of archeology and history concerning Texas and its bordering states of Louisiana, Arkansas, Oklahoma, New Mexico and Northern Mexico; a region we call the "Texas Borderlands." The J.T.A.H. is collaborating with the Index of Texas Archaeology and S.F.A.S.U. to distribute their publication library to the general public via free and open-access channels. Visit www.JTAH.org to submit an article. 


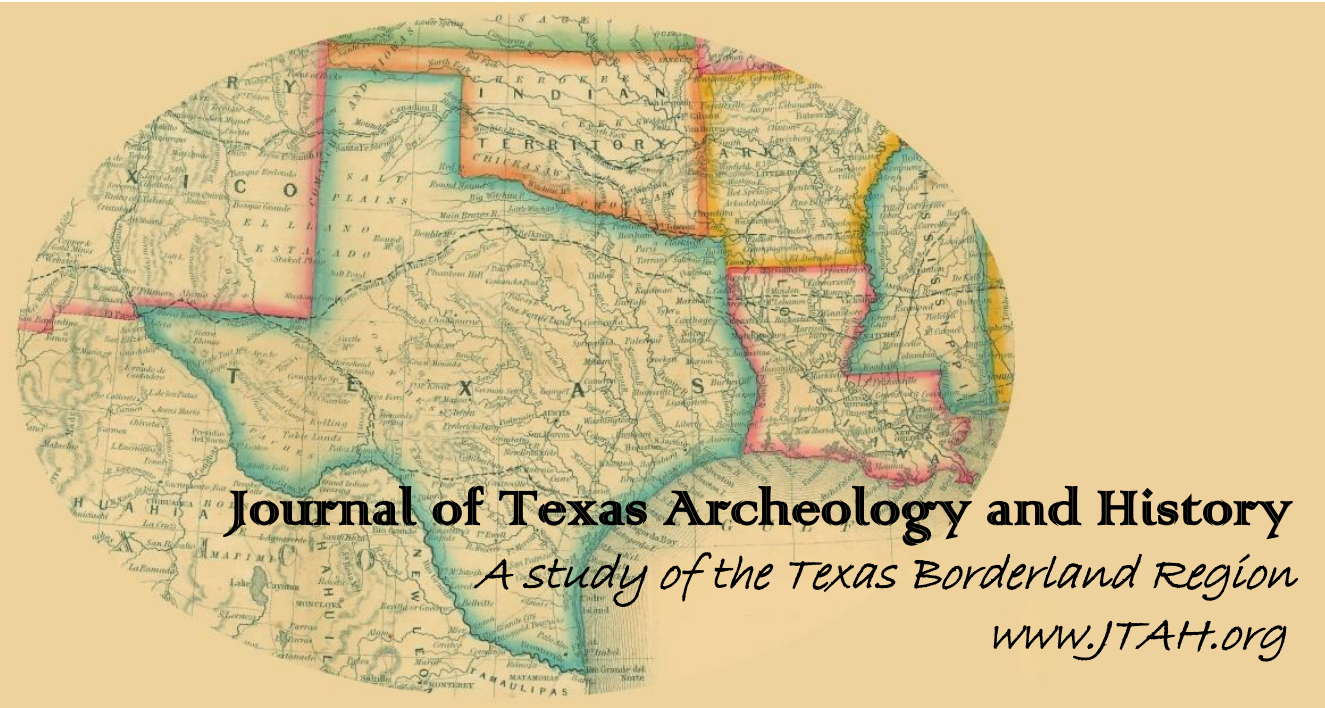

\title{
Article Title: $\quad$ POST OF LAMPASAS: FORGOTTEN RECONSTRUCTION ERA U.S. ARMY POST (1867-1870)
}

\author{
Author(s): $\quad$ Richard S. Jones
}

Original Source: J.T.A.H. Volume 1 (2014), pp. 27 - 50; online 13 November 2014

Recommended Citation: Jones, Richard S., "Post of Lampasas: Forgotten Reconstruction Era U.S. Army Post (1867-1870)", (2014), Journal of Texas Archeology and History Volume 1 (2014), pp. 27-50.

Copyright $@ 2014$ by Journal of Texas Archeology and History.org, Inc. All rights reserved. Online/Digital publication: ISSN 2334-1874

The online, digital and print versions of the publication "Journal of Texas Archeology and History" are published by Journal of Texas Archeology and History.org, Inc., a Texas nonprofit IRC Section 501(c)(3) corporation.

Reproduction, posting, transmission, or other distribution or use of the Journal volume, individual article or any portion of the material therein, in any medium, is permitted strictly for personal, non-commercial purposes via a personal-use exemption under a Creative Commons license granted by JTAH.org, Inc. This license exemption requires, as a condition of its granted permission, proper credit be attributed to JTAH.org as copyright holder (e.g., Journal of Texas Archeology and History.org (C) 2014). No part of this publication may be reproduced, posted, transmitted, or otherwise utilized or distributed in any form by any means or method for commercial purposes without the express written consent of the Publisher. Inquiries should be addressed to JTAH Publisher, Suite 307, Box 361, 5114 Balcones Woods Drive, Austin, Texas, 78759

The Journal of Texas Archeology and History.org is an organization dedicated to furthering research, education and public outreach in the fields of archeology and history concerning Texas and its bordering states of Louisiana, Arkansas, Oklahoma, New Mexico and Northern Mexico; a region we call the "Texas Borderlands." The J.T.A.H. is collaborating with the Index of Texas Archaeology and S.F.A.S.U. to distribute their publication library to the general public via free and open-access channels. Visit www.JTAH.org to submit an article. 


\title{
POST OF LAMPASAS: FORGOTTEN RECONSTRUCTION ERA U.S. ARMY POST (1867-1870)
}

\author{
Richard S. Jones
}

\begin{abstract}
While it is well known that troops were stationed in and around Lampasas during the Reconstruction era (1865-1877), the existence of an army post in Lampasas County, Texas, has been rediscovered through the recent digitization of army post returns. The post returns, available through the U.S. National Archives and Records Administration and Ancestry.com, indicated that the post operated between 1867 and 1870 . These post returns are utilized to highlight significant events that occurred in this area during the Reconstruction era. Circumstantial evidence obtained while conducting this research has identified the actual location of the post within the City of Lampasas.
\end{abstract}

\section{INTRODUCTION}

A letter from W. B. Pace, Chief Justice of Lampasas County and four citizens to Texas Senators Burney and Cooley, dated August 15, 1866, stated that:

This is one more to the long list of depredations that have been committed on the frontier within the past fifteen months, and which are now of almost daily occurrence. It is not our wish to exaggerate the reality is bad enough. It will be observed that these depredations are now extended to Cattle, and not confined, mostly, as heretofore, to horses...This shows the audacity of the parties, and the impunity with which they expect to carry on their robberies. This country used to count its horses by the thousands, now scarcely a hundred can be mustered, and still the work goes on, each moon, diminishes the number of stock and settlers and unless a remedy is applied, and that immediately, the Frontier will and must be abandoned... Can the Government be ignorant of our situation? We think not, will it continue to be deaf to the call of justice and humanity? We trust not. Then why delay, when the lives and property of its citizens are in danger? Is there any interest of more vital importance, or that requires more immediate action? (Jackson, McCaleb, Mullins, Pace, and Townsend 1866).

From this letter, it is evident that the citizens of Lampasas were living in fear; one must ask whether or not the U.S. Government answered the call for aid. Until my recent analysis of post returns, it was believed that very little, if any, aid was provided by the U.S. Government during this

\footnotetext{
JOURNAL OF TEXAS ARCHEOLOGY AND HISTORY

VOLUME 2:27-50

THE ONLINE PUbliCATION JOURNAL OF TEXAS ARCHEOLOGY AND HISTORY (ISSN 2334-1874)

IS PUBLISHED BY JOURNAL OF TEXAS ARCHEOLOGY AND HISTORY.ORG.

COPYRIGHT (C) 2014 JOURNAL OF TEXAS ARCHEOLOGY AND HistORY.ORG. All RIGHTS RESERVED.
} 
time. Until recently it was thought that the aid provided by the government consisted only of setting up a temporary encampment that was sometimes used by a cavalry detail (Clardy et al. 1991; O'Neal 2012). This article delves into the violent background of the Lampasas area around the mid-nineteenth century and provides evidence that proves the U.S. Government did indeed answer the call for help from the citizens of Lampasas by establishing U.S. Army Post Lampasas.

\section{HISTORY OF VIOLENCE}

The chaotic and violent nature of the Reconstruction period in Texas has its roots both in U.S. Government Indian policies as well as the greatest conflict this Nation has ever faced, the Civil War, which strained the very fabric of the Nation and had an adverse impact on almost every man, women, and child that lived in this country at the time. From the Civil War extending into the Reconstruction period, areas surrounding Lampasas County, including Hamilton, Coryell, and Bell counties, were under constant threat of attack from Comanches and numerous outlaw gangs, as well as the threat of mob violence primarily conducted by groups like the Ku Klux Klan (KKK) that were very active in this region by 1868 (Howell 2012).

\section{Comanches}

The Comanche were by far the most populous Indian tribe in Texas with around 20,000 members reported in 1849 to 1851, according to population estimates by Indian agent Robert Simpson Neighbors and ethnologist Frederick Webb Hodge (Kavanagh 1996). Their territory during the late eighteenth to early nineteenth centuries included a vast expanse of land including northeastern New Mexico, southeastern Colorado, western Oklahoma, the Texas panhandle, and the Central Texas Hill Country (Gelo 2013). In the nineteenth century, the Comanches were comprised of six bands/divisions: Kotsotecka (Buffalo Eaters), Yamprika (Root Eaters), Kwahadi (Antelope), Nokoni (Wanderers), Penateka (Honey Eaters, Wasps), and Tenewa (Downstream People) (Gelo 2013). The area around Lampasas and adjacent areas were within the range of the Penateka band/division (Richardson 1933). Muguara was the Peneteka division leader until his death in 1840, after which Buffalo Hump, Ketumse, Sanaco, and Yellow Wolf filled the breach (Gelo 2013). Raids against Anglo-Americans increased after 1840 when the Comanches formed an alliance with the Kiowa and Cheyenne to stop the Anglo-American western expansion. This effort was largely successful during this time and towns such as Lampasas were under the constant threat of attack. O'Neal (2012:15) summarizes the conditions in the Lampasas area:

From 1857 to 1874 , usually in the spring and summer, Comanches raided at will in Lampasas County. The raiders stole large numbers of horses, often at night under a "Comanche Moon," and sometimes murdered and mutilated unwary settlers. This long Comanche menace retarded population growth, forced many settlers to leave for a safer county, and filled others who stayed with a nagging fear. The Lampasas Dispatch reported that in 1871, "the population of the county was about fifteen hundred, and they lived in constant dread of the murdering savages of the plains." 
News reports at the time reflect similar sentiments. For example, the Southern Intelligencer (SI) reported in March 1866 that an Indian raid occurred where "a large number of horses, the number being variously estimated at from two to four or five hundred" were taken; locals lamented that: "[w]e are now waiting to hear of help from some quarter. If the government knew our conditions, they undoubtedly would lend a helping hand. The marauders took nearly all the horses in the town of Lampasas" (SI, March 1, 1866).

In Texas, the homeland of the Comanches was not secured by the U.S. Government until after the Civil War when several treaties were made and reservation set up within Texas and later in western Oklahoma. However, resistance by Comanches to reservation settlement continued until their unsuccessful attack on the Adobe Walls trading post, after which they were forced back onto the reservation in a concerted campaign by the U.S. Army between 1874-1875 (Gelo 2013).

\section{Outlaw Gangs}

During the Civil War, the region was a safe haven to numerous outlaw gangs comprised of confederate and union deserters, profiteering horse/cow thieves, and outcast union civilian sympathizers (Cooper 1863; McCulloch 1864). These gangs were generally attracted to areas surrounding Cowhouse Creek and the Lampasas River because of several factors: (1) the region's remote location on the frontier; (2) virtually no law enforcement presence; (3) dense concentrations of cedar thickets that provided highly defensible positions; and (4) support from some in the local populace who backed Sam Houston and his belief in not seceding from the Union.

Two of the main gangs that were active in Hamilton, Lampasas, Coryell, and Bell counties were led by Elisha (or Lige) Bevins and Samuel S. Gholson, both of whom were confederate deserters. According to reports, the two gangs had around 100 to 300 men that roamed the area stealing at will and threatening the local populace (Cooper 1863). Confederate Major John Henry Brown in a July 1863 letter to Major General Magruder believed them to be an armed Union guerrilla force that was in secret consultation with noted Union sympathizer George Washington Pashal (Brown 1863). Major Brown also stated that he had information from spies that had infiltrated the gangs that they were actively plotting executions and attempting to stockpile weapons from Mexico for some unknown purpose (Brown 1863). In response to this letter, General Magruder sent Company B, 37 Texas Calvary led by Captain George Cooper to the area for a temporary assignment in August 1863. While the gangs still avoided capture, Captain Cooper and his men were successful in temporarily lowering tensions in the area. As their assignment came to an end the citizens of Bell County, fearing a return to gang violence, petitioned General Magruder to allow Captain Cooper to stay until the gangs were dealt with (Petition from Citizens of Bell County 1863).

Of note, one of the modus operandi of these gangs was to dress up in Indian garb in order to fool victims and settlers into believing Indians were responsible. One story reported in the Weekly Telegraph (WT) in November 1863 stated: "One Thomas Fulgum and others have been arrested in Coryell County, having in their possession an abundance of Indian arrows, moccasins, and other Indian disguises, by the aid of which they had been playing Indian on the frontier, stealing, shooting stock, 
etc. They were in communication with men who had deserted and concealed themselves in the woods. One Augustus (Gus) Fore was associated with the same gang of deserters" (WT, November 17, 1863). Gus Fore was a known member of the Lige Bevins gang (Brown 1863). Another story reported in the Georgetown Watchman (GW) in June 1869 reported that "[w]e are informed by Mr. D. T. Guinn, just down from Lampasas Springs, that the late Indian depredations reported in the county are erroneous. That there have been depredations committed is true, but the depredators are white men" (GW, June 5, 1869).

The Bevins and Gholson gangs that roamed the area were eventually routed and defeated by a combined force led by Captain George Cooper from Company B, 37 Texas Cavalry, a civilian volunteer mob led by Belton resident Dred Hill, and a squad of men from Company B, 30 Texas Cavalry. This campaign lasted over five months (August to December 1863) and ended when Lige Bevins was captured and hung with several comrades while Gholson and remaining stragglers fled toward Mexico before getting stopped by Confederate Forces near Eagle Pass (Brown 1863; Frontier Times [FT], July 1926; WT, December 1, 1863; Williams 1930-1934). Following the Civil War, Gholson was known as one of the best cattle men and frontiersman of his day, having established his own cattle ranch in Coleman County before moving to New Mexico where he was reported to have teamed up with legendary ex-Texas Ranger Ira Aten, range boss of the vast XIT Ranch (Dallas Herald [DH], May 25, 1872; FT, February 1927 and July 1928; Gillett 1921:9-10; Intelligencer-Echo [IE], November 4, 1874; Stevens 1975; Williams 1930-1934).

Of further interest, the possible association of gangs in the region with Union forces first suspected by Major John Henry Brown in 1863 is corroborated in a May 20, 1864, letter from Captain William Pace, who commanded the Confederate Second District State Troops in Lampasas. In this letter Captain Pace noted:

Sir: William E. Willis and Gideon Willis came into this county about ten days ago from Mexico, for the purpose, as they say, of recruiting for the Federal Army, and taking a list of all would be Union men. They have recruited until their forces are said to be about 100 strong. They pass over the country in small parties with perfect impunity, and threaten destruction of property of secessionists. In view of these outrages and the fatal results of a longer stay in the country by them, we beseech you to come immediately to our relief (McCulloch 1864).

Major General McCullouch, Commander Northern Sub-District, forwarded Captain Pace's letter to Brig. General J. E. Slaughter, Chief of Staff, on May 30, 1864 with the accompanying statement:

General: I herewith transmit a letter from Captain Pace to Lieutenant Colonel Jackson, which will call your attention to the condition of affairs on our border. Lampasas is in the edge of a rough mountainous region, which extends to the Concho country, and I have no doubt a large portion of the deserters and disloyal men who are embodied are in that region of country, and if it were to clean out all that country, commencing on Cowhouse Creek and Lampasas, Pecan bayou, Colorado, Concho, and notify me of the time, so that I could co-operate with them from above that place. I do not know that any force can be spared 
from below, but this section is far from me, out of my district, and needs immediate attention, if it is possible to give it, and I feel that it is my duty to so inform the general commanding (McCulloch 1864).

When the Civil War ended, many of these deserters and criminals ended up settling in this region, with some becoming honorable citizens while others continued their criminal lifestyle. Notable outlaws that were active in the area during the Reconstruction period included: John Wesley Hardin, the James Gang, Sam Hasley, John Early, William Perryman, the McRae Gang, Ace Langford, King Fisher, Bat Masterson, the Horrell brothers, and the Shackelford Gang, to name a few (For a complete history of outlaw violence in the Lampasas area the reader is referred to O'Neal [2012].)

\section{Mob Violence}

In addition to threat of attack from Indians and outlaws, the citizens of Texas during the Reconstruction period also had to deal with the specter of organized mob violence. During this period Texas was home to more than 60 organized groups that went by various names, including the KKK, the Knights of the White Camellia, the Teutonic Knights, the Sons of Washington, the White Brotherhood, and the Knights of the Rising Sun. All these groups were generally comprised of exconfederate Anglo-Americans that were committed to perpetuating violence against minorities, freedman, and the occupying Union forces. In particular, the newly established Freedman's Bureau locations and employees were a favorite target of these groups (Howell 2012). Violence and lynching's from these type mobs in Texas persisted throughout the Reconstruction period and into the midtwentieth century in many local communities.

\section{POST LAMPASAS}

Based on the information presented above, it is clear the settlers in the Lampasas area lived in a constant state of fear every day of their lives for almost a quarter of a century (1853-1875). During the early Reconstruction period, the violence was so severe that citizens including W. B. Pace, Chief Justice of Lampasas, pleaded to the U.S. Government for help. From recently digitized post returns, it is now known that on May 30, 1867, the U.S. Government finally came to the aid of the citizens of Lampasas by establishing a post within the city that was permanently occupied by a company of soldiers from the 26th Infantry, and later 4th Calvary, from 1867 to 1870. From detailed entries within these post returns it is now known that the soldiers of Post Lampasas were tasked to protect the local populace from attacks from both Comanches and outlaw gangs. They were sent on multiple scouts to

make their presence known on the frontier and to also search and destroy any hostile parties encountered, with some U.S. soldiers even losing their lives while performing these duties.

A substantial amount of historical information regarding the activities and duties of soldiers stationed at Post Lampasas can be gleaned directly from the post returns that the U.S. Army required every post commander to fill out every month (Figure 1). These post returns are a valuable and often underutilized primary resource that show monthly summaries of events, deaths, wounded in action, desertions, units present, numbers of soldiers and officers present/absent/sick, numbers of horses and 


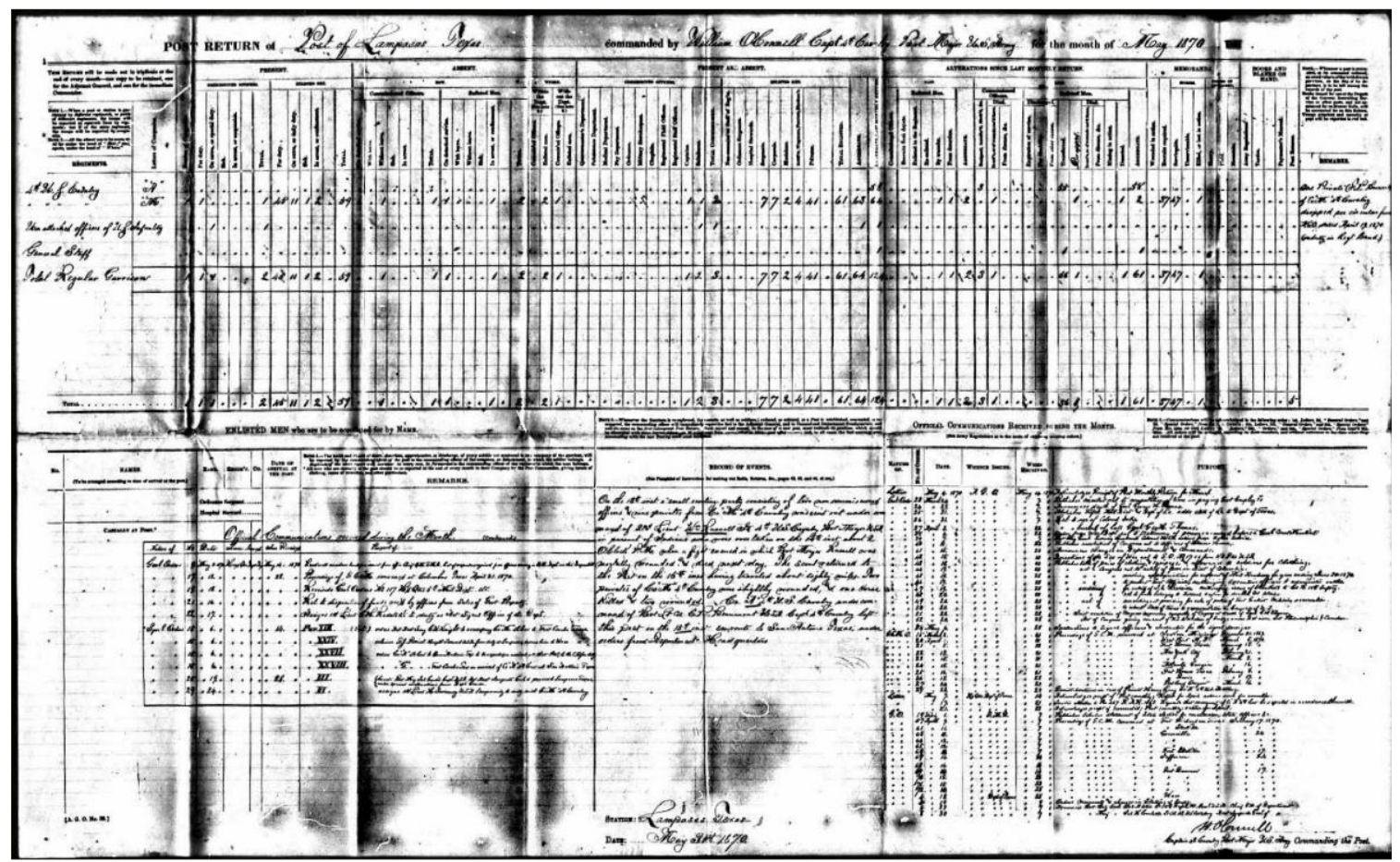

Figure 1. Post of Lampasas post return dated May 1870 (National Archives and Records Administration, Washington, D.C.)

artillery, and official communications (see Appendix 1). These post returns have recently been digitized and are available for viewing at the U.S. National Archives and the website Ancestry.com.

Prior to my analysis of post returns from Post Lampasas, recent publications (Clardy et al. 1991; O'Neal 2012:25) described troops stationed at Lampasas as never occupying more than a temporary encampment:

But none of the reopened or new forts were near Lampasas, and Comanches continued to raid throughout the county. So a cavalry detail sometimes was assigned to Lampasas, camping in the grove at Hancock Springs. There were no permanent buildings, so this little outpost was not designated "fort" or even "camp."

In this article, the analysis of post returns has filled the void regarding what was previously known about this post, and these post returns clearly indicate that the U.S. Government did indeed answer the citizens of Lampasas' call for help and established a post that was permanently occupied by U.S. Army troops from 1867-1870. In addition, the post returns designate this location as an actual U.S. Army post called "Post Lampasas." It is evident that the post was not just a temporary encampment that was intermittently utilized by a cavalry sensu O'Neal (2012). 


\section{UNITS, OFFICERS, AND EVENTS}

The following sections contain a summary and discussion of the units that were stationed at the post, notable officers, and significant events. All of this information can be found within the post returns that were submitted by the commanders of Post Lampasas between 1867 to 1870 (Appendix 1).

\section{Units}

Based on information contained in the post returns, Figure 2 represents the overall number of soldiers stationed at Post Lampasas during this three year period.

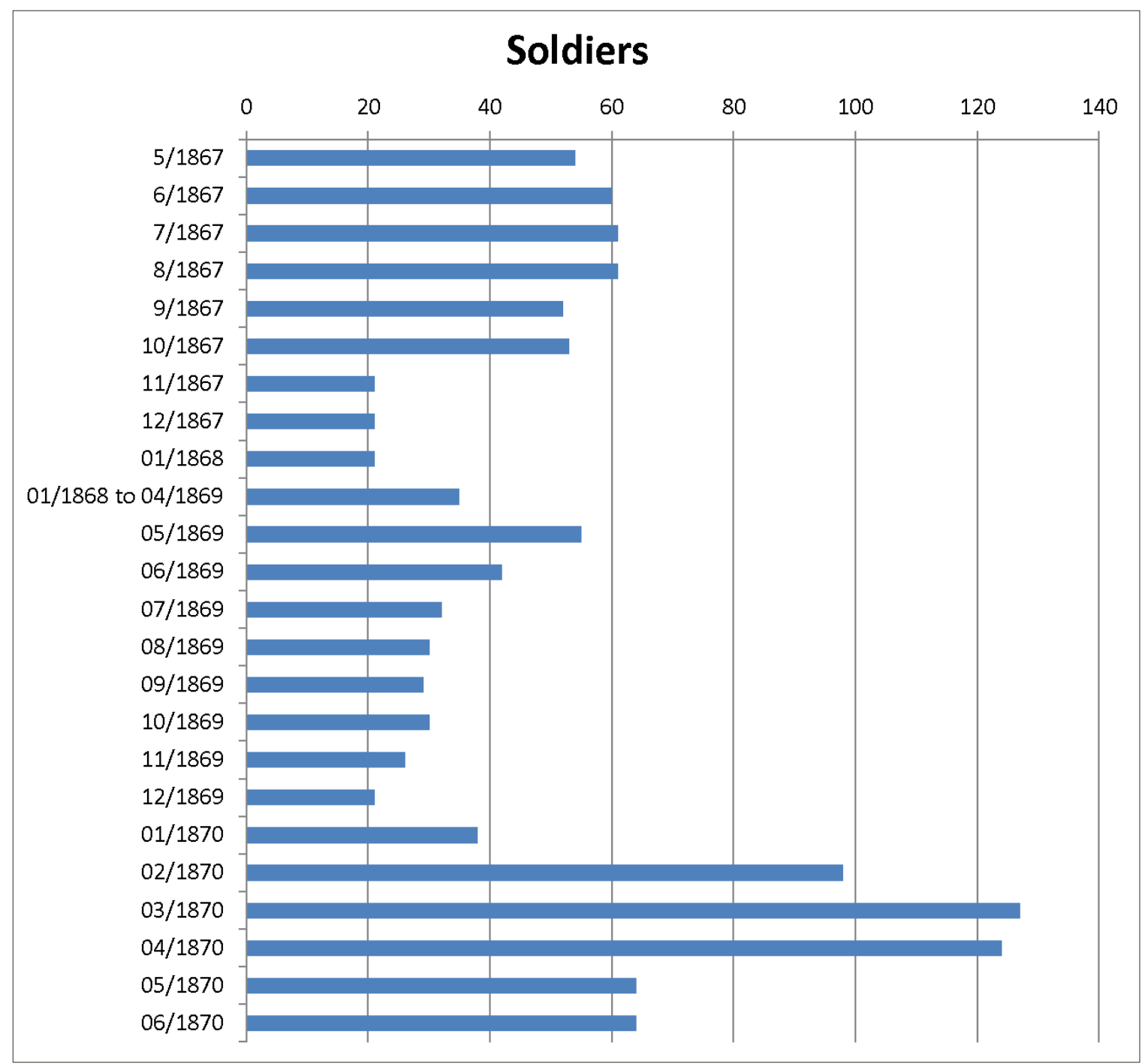

Figure 2. Number of soldiers stationed at Post Lampasas (From U.S. post returns 1867-1870). 


\section{May 1867 to January 1868: 26th Infantry, Company K}

The 26th was a company out of Austin that was the first stationed at Post Lampasas. The 26th Infantry was moved to the Rio Grande valley in January 1868.

\section{January 1868 to March 1869: 17th Infantry, 2nd Battalion}

Post returns for the 17th and 35th Companies while stationed at the post either were not completed, were lost, or were not turned in by the post commanders. It has been documented that the 17th Infantry, 2nd Battalion was stationed in Austin to assist in frontier defense. According to Richter (1987:180), elements from the 35th Infantry were sent in March 1869 to relieve elements of the 17th Infantry in frontier garrisons within Texas. The mention of 35th Infantry troops on the post returns in May 1869 suggests that there were troops from the 17th Infantry stationed at this garrison before the arrival of the 35 th.

\section{March 1869 to May 1869: The 35th Infantry, Company $H$}

This company likely relieved elements of the 17th around March 1869 (Richter 1987). Proof for the presence of 35th Infantry, Company H is found in the May 1869 post return completed by the 4th Cavalry post commander and also in the May 8, 1869 Georgetown Watchmen newspaper article that mentioned the post was commanded by 35th Infantry, Company H 1st Lieutenant Thomas Stevens. The Post Lampasas commissioned officer roster also listed 1st Lieutenant Stevens as present during May 1869.

\section{May 1869 to June 1870: 4th Cavalry, Companies $A$ and $M$}

These companies were sent out of Austin and, thereafter, were stationed at the post. The 4th Cavalry, Company A under Captain Beaumont was sent to San Antonio in April 1870. Company M under the command of Captain William O'Connell closed the post in June 1870 and was then sent to Fort Concho.

\section{Notable Officers}

\section{Eugene Beauharnais Beaumont (August 2, 1837-July 17, 1916).}

Eugene Beaumont was a graduate of the United States Military Academy at West Point in 1861, ranking 32nd out of 45 cadets. He was a Union Army officer in the Civil War (Figure 3) and a recipient of the United States Military's highest decoration, the Medal of Honor. His Medal of Honor Citation reads, in part:

Obtained permission from the corps commander to advance upon the enemy's position with the 4th U.S. Cavalry, of which he was a lieutenant; led an attack upon a battery, dispersed the enemy, and captured the guns. At Selma, Ala., charged, at the head of his regiment, into the second and last line of the enemy's works. After Civil War served with 4th Cavalry on numerous Texas posts including: Camp Sheridan, Fredericksburg, Ft. Mason, Ft. Chadborn, Ft. McKavett; Lampasas, San Antonio, Ft. Richardson, and Ft. Clark (Cullum 1920:802). 


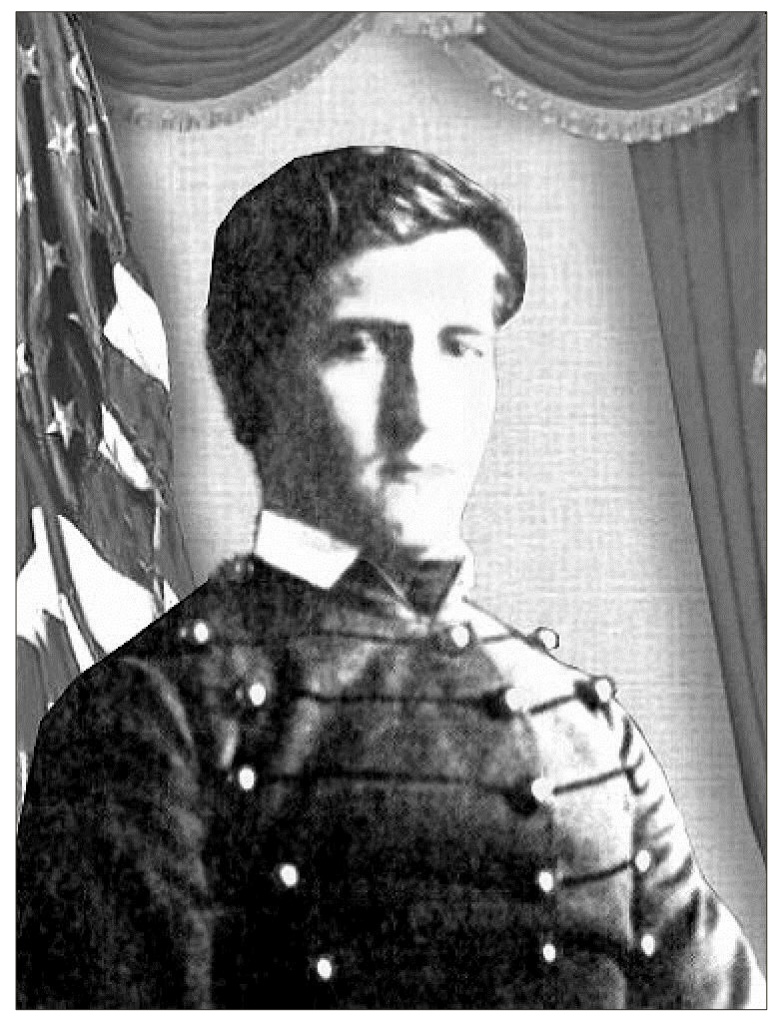

Figure 3. Eugene Beaumont, Civil War portrait. Photo courtesy of: www.homeofheroes.com.

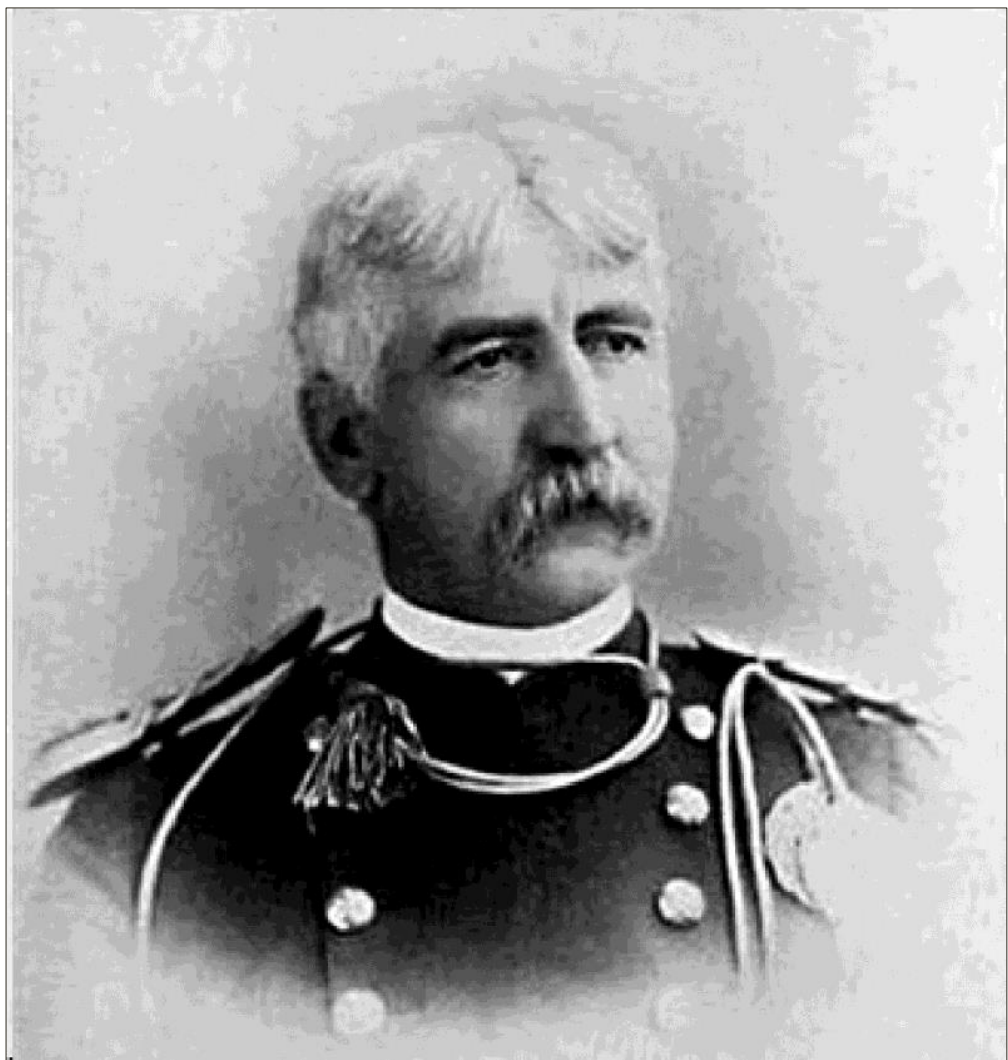

Figure 4. Eugene Beaumont, later service photo. Photo courtesy of: www.Findagrave.com. 


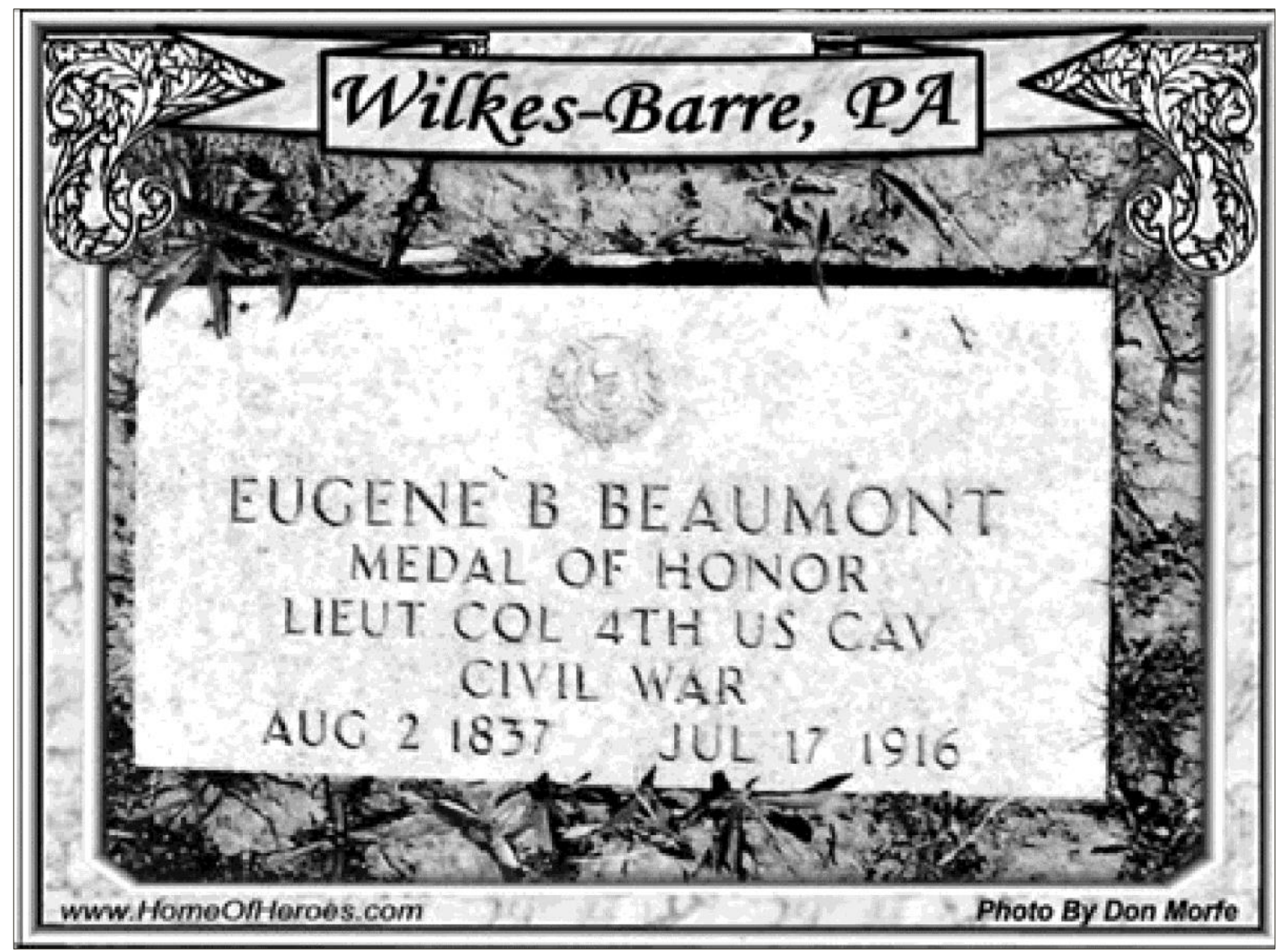

Figure 5. Eugene Beaumont headstone in Hollenback Cemetery, Wilkes-Barre, Pennsylvania. Photo courtesy of www.homeofheroes.com.

At Fort Clark, Beaumont was engaged in the attack on the Kickapoo and Lipan villages in Mexico on May 18, 1873. At Fort McKavett, he led an expedition into Indian Territory from August 18th to December 29, 1874. Beaumont commanded a battalion of 4th Cavalry troops in the fight at Palo Duro Canyon on September 28, 1874, which resulted in the destruction of numerous camps and the capture of 1700 horses and mules, and the defeat of a band of Comanches (Carter 1935:25). Beaumont also served as Assistant Instructor of Cavalry Tactics at the Military Academy from March 1, 1875, to August 28, 1879. He retired on May 6, 1892, as a Lieutenant Colonel (Figure 4). Beaumont died at the age of 78 in Harvey's Lake, Pennsylvania. He was buried in Hollenback Cemetery in his hometown of Wilkes-Barre, Pennsylvania (Figure 5).

\section{William O'Connell (date unknown)}

William O'Connell was born in Ireland and served as an enlisted man in the Dragoon Detachment at the U.S. Military Academy. In April 1855, he transferred to the 1st U. S. Cavalry. O'Connell was promoted to First Sergeant in June 1855. He served at Fort Leavenworth in 1857 and participated in the Cheyenne and Utah expeditions of 1857 and 1858. He also served at Fort Riley, Fort Smith, Indian Territory, and Fort Arbuckle. In 1860, he engaged in the Kiowa and Comanche Indian expedition and later participated in the Battle of Wilson's Creek, Missouri. 
In October 1861, he was promoted to Second Lieutenant in the 4th U.S Cavalry and attained First Lieutenant in 1862. O'Connell served with the Army of the Potomac in Maryland and Virginia in 1863 and the Army of the Cumberland in 1863. He commanded a regiment in Alabama and Georgia from March to May 1865, and was transferred to Texas in 1866; he was promoted to Captain in 1869. O' Connell was awarded Brevet Captain for gallant and meritorious services in action at Middleton, Tennessee, and Brevet Major for gallant and meritorious services at the capture of Selma, Alabama. He was stationed at Post of Lampasas, Texas, in 1870 and later transferred to Fort Concho (Henry 1873:160). Captain O'Connell was described as one of the best old Irish soldiers in the U.S. Army (Carter 1935:35). He died in 1895 and was interred in the San Francisco National Cemetery, California.

\section{Significant Events}

\section{May 1867 to January 1868: Post Established}

Post Lampasas was established May 30, 1867, per Special Order No. 50. The 26th Infantry, Company $\mathrm{K}$ was then stationed at the post. A skirmish with citizens occurred at 10 p.m. on June 17 in which 2nd Lieutenant Roe and 16 men participated. 1st Sergeant George C. Lyon and Private Track were wounded. Private Henry Pearson died June 4, 1867 of typhoid fever. Private Pearson is likely still buried at the post. Private Daniel Jones, Company L 6th U.S. Calvary, died at the post on September 17, 1867, from wounds received while in discharge of duty on August 17, 1867, near Lampasas, Texas. Private Jones is likely also still buried at the post. The incident is recorded in the Georgetown Watchman, which describes the shooting of Mr. Jackson, a local merchant, "and probably the death of a soldier" killed by "three men, who were armed each with a double-barreled gun and two six-shooters. They had just before driven away the inmates of a house in the suburbs of the town [Lampasas] and robbed it. They resisted, and a running fight ensued, in which Mr. Jackson was shot dead, and one of the soldiers shot through the lungs"(GW, August 24, 1867). The post was evacuated per Special Order No. 228 HQ District of Texas, Austin, Texas, on December 28, 1867. The 26th Infantry, Company K then left Post Lampasas.

\section{January 1868 to May 1869: Lost Post Returns}

The 35th Infantry, Company H left this Post May 17, 1869. Complete Post returns for the 17th and 35th Infantry units, which would show events during the period from January 1868 to May 1869, were either not completed by the commander or were lost.

\section{May 1869 to June 1870: Scouting Parties and Post Closure}

The garrison had been employed in furnishing escorts and scouting parties to the Sheriff and other civil authorities during this time period. Each of these is listed in further detail below:

- Unsuccessful pursuit (May 25th, 1869): 2nd Lieutenant James H. Jones 4th Cavalry left on May 22 with six men and a non-commissioned officer in an unsuccessful pursuit of J. W. Nash (or J. McNash), an absconding Deputy Colonel of a Reserve unit from Burleson County. 
- First scout (June 17, 1869): a detailed 10 day route of scout consisting of 26 enlisted men and one officer is provided under Record of Events. The scout covered 200 miles and traversed west to the San Saba area, north to the abandoned Civil War Confederate Camp Colorado (south of Brownwood), northeast across Pecan Bayou, south to San Saba, and then returned to Post Lampasas. No Indian signs were discovered.

- Second scout (June 28, 1869): approximately 20 men left the post in an unsuccessful pursuit of Indians that were reported to have attacked herders and driven off 100 horses 10 miles from the post. The distance traveled was 200 miles.

- Third scout (March 14, 1870): Captain E. B. Beaumont, 2nd Lieutenant James H. Jones, and 25 enlisted men left the post on a scout for Indians. The detachment proceeded to Antelope Gap, Lampasas County, a distance of 25 miles and there encamped. Five Indians with more were seen but the soldiers did not camp for want of a competent guide with the detachment. The scout returned to the post on March 19, 1870, for want of forage after marching a distance of 85 miles.

- Fourth scout (April 13, 1870): 2nd Lieutenant James H. Jones, 4th U.S. Cavalry, with a detachment of 25 enlisted men left the post to watch the mountain passes at Antelope Gap, Lampasas County, with the intent of intercepting bands of hostile Indians. The detachment was out 10 days and returned for want of forage. No Indians were seen or heard during the distance marched, over 90 miles.

- Fifth scout (May 18, 1870): A small scouting party consisting of two non-commissioned officers and nine privates from Company M, 4th Cavalry, was sent out under command of 2nd Lieutenant (Brevet Major) William Russell (Figure 6) in pursuit of Indians. The Indians were overtaken at Mount Adam, Lampasas, Texas, on May 14, 1870, at about 2 p.m. and in the ensuing skirmish 2nd Lieutenant Russell was mortally wounded. The scout returned to the post on May 15, having traveled about 80 miles. Two privates of Company M, 4th Cavalry, were slightly wounded, one horse was killed, and two horses were wounded.

Second Lieutenant Russell died at midnight, May 15th, in the line of duty. The surgeon's report indicated "the ball from a Remington revolver, entered just beneath the tenth rib of the right side, at about four inches from the vertebral column" and that "a citizen extracted the ball by incision some two hours before the writer arrived upon the spot. There had been extensive hemorrhage" (Otis 1871:51). The surgeon decided an autopsy would be impractical but suggested the ball likely penetrated Russell's liver, and the immediate causes of death seem to have been the shock of the injury and the hemorrhage (Otis 1871:51). Second Lieutenant Russell was initially buried at Post Lampasas but was moved two years later and interred at Albany Rural Cemetery, Albany, New York. This incident was covered by numerous Texas newspapers such as the Belton Weekly Journal, which reported the particulars of this sad event: 


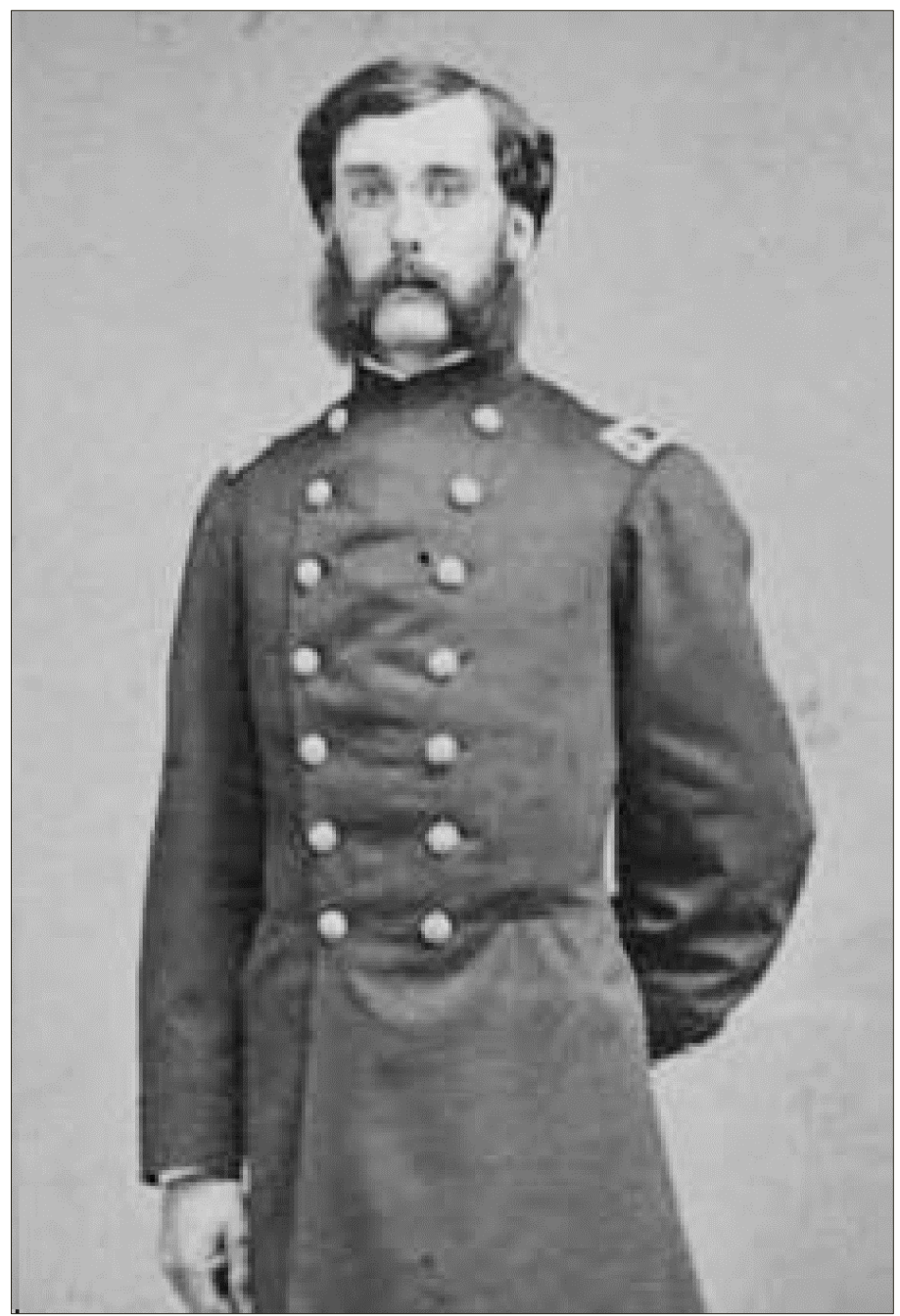

Figure 6. 2nd Lt. (Brevet Major) William Russell Jr. Photo courtesy of New York State Military Museum.

After the charge, the Major seeing the unequal position, ordered 'dismount and retreat in front of horses' which gave evidence of discretion and coolness; but most unfortunately as he was in the act of alighting he received a mortal wound which took effect in the region of the liver. The Commander being thus cut down so early in the action, of course, gave rise to more or less confusion; consequently the fighting ceased and the Indians in a manner were the victors. However, the general impression of those who were present is, that had not the gallant Major been so unfortunate at the particular crisis he would have whipped them and recaptured all the stolen property (The Belton Weekly Journal, May 28, 1870).

\section{DISCUSSION}

Post Lampasas was established by the U.S. Army at the request of citizens of Lampasas County for the purpose of providing frontier protection to residents who suffered continual attacks from both Comanches and outlaw gangs. Despite being undermanned at times, the troops stationed there did an exemplary job performing their mission during the three years (1867-1870) the post was active. 
The analysis of the post returns was a key factor in providing a clear understanding of this Reconstruction era post on the frontier that has never been fully researched and studied by historians. The post returns revealed that Post Lampasas was anything but a temporary encampment that was sporadically utilized as a campsite with no permanent buildings (cf. O'Neal 2012:25). On the contrary, the post returns suggest this installation was in fact a well-established U.S. Army Post that was permanently occupied between 1867 to 1870 by hundreds of soldiers from two infantry and two cavalry companies. Post returns revealed that these troops were active building stables and other infrastructure. This likely indicates that Post Lampasas would have had a number of permanent wooden structures (with rock fireplaces) used to house troops during the approximately three years of occupation.

While the exact location of Post Lampasas was never mentioned in the post returns, I was able to ascertain its location by assembling strong circumstantial evidence uncovered in newspaper reports and the Post Return Officer Roster. The key to confirming the location was found in a newspaper article in the Georgetown Watchman. The newspaper article states "Col. Stevens is in command here with two companies Infantry and one of Cavalry. They have a beautiful camp around the oaks at the upper springs" (GW, 8 May 1869). This Colonel Stevens is in all likelihood 1st Lieutenant (Brevet Captain) Thomas Stevens, who commanded Company H, 35th Infantry while the unit was stationed at Post Lampasas and left May 17, 1869, just nine days after this newspaper article was released. Also, this article mentions that the post is located around the oaks of the Upper Springs. The name Upper Springs is another key in locating the post.

Historian Bill O'Neal (2012:3) writes that in Lampasas “...to the southwest, in a magnificent grove of shade trees, was a bubbling spring with the greatest flow in the area. Because of the location it was often called the Upper Springs; because of its bubbling action (not its brisk, cool temperature) it was sometimes known as the Great Boiling Spring; it also occasionally was called Rock Springs. But within a few years it would become Hancock Springs, after settler John Hancock acquired the property." Accordingly, Upper Springs is most likely one and the same as Hancock Springs, and the presence of 1st Lieutenant Stevens mentioned above confirms that Post Lampasas is at this location. Since the post was abandoned in 1870, the current area around Hancock Springs (Figure 7) has been significantly altered with a golf course, roads, buildings, and parking lots covering much of the area. However, it cannot be ruled out that remains of the original Post Lampasas including such features as building foundations, piles of rock from toppled chimneys, activity areas, and other features remain hidden in the ground waiting to be discovered through archeological investigations.

The analysis of post returns has led to the discovery and reporting of the existence of this previously unknown Reconstruction era U.S. Army post. It is hoped that by demonstrating the importance of these documents, more historians and scholars will utilize this primary source material that has been digitized and is now easily accessible. When combined with traditional secondary source materials, researchers studying historic U.S. Army garrisons should arrive at a more accurate understanding of what was actually taking place at these historically significant sites, clearing a path for future research. 


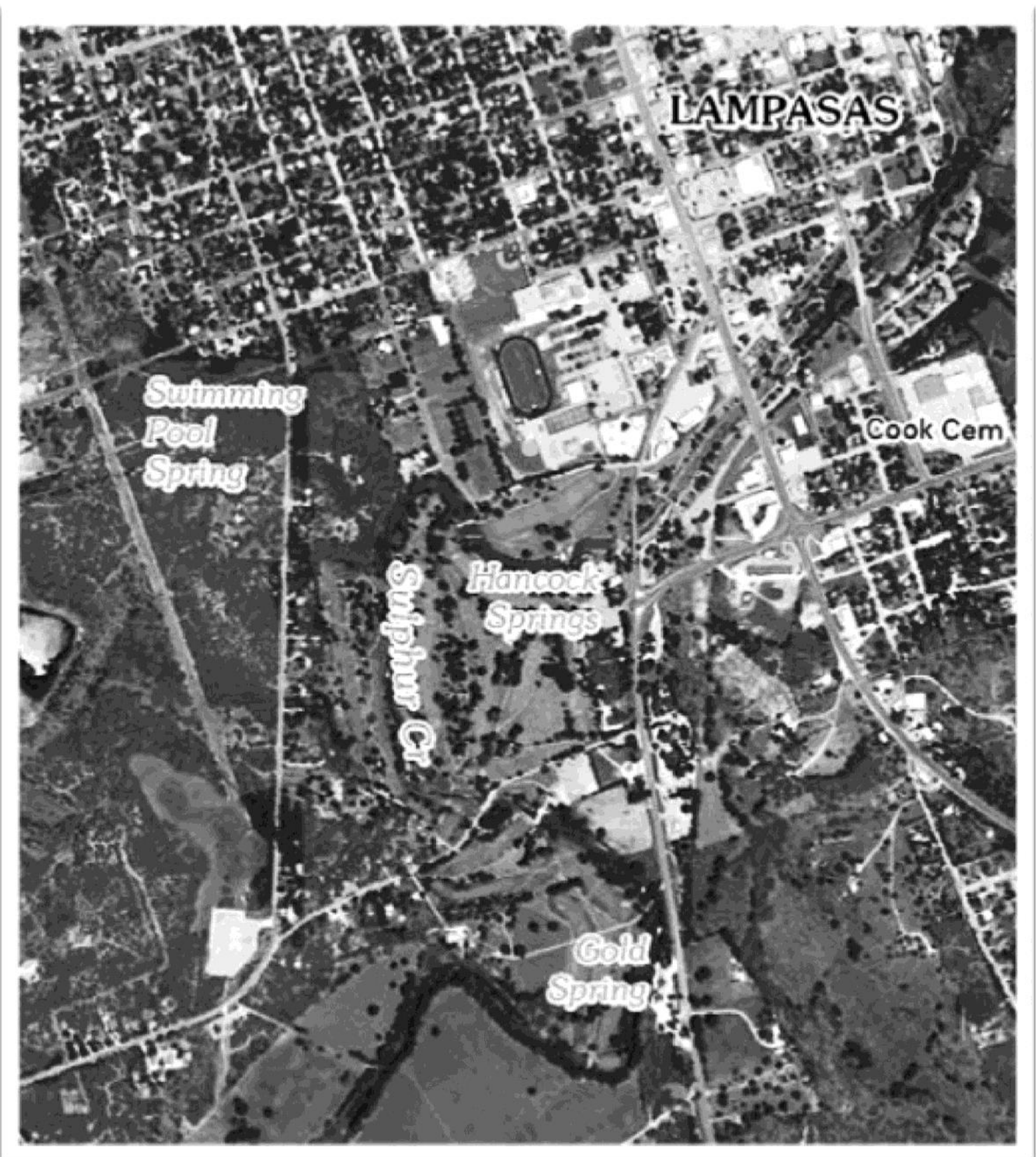

Figure 7. Current map of Hancock springs area, Lampasas County, 2013.

\section{REFERENCES CITED}

Belton Weekly Journal (BWJ)

1870 Fatal Rencontre With Indians. May 28, 1870, Volume 4, No. 23. Belton, Texas.

Brown, Major J. H.

1863 Letter from Major Brown to Major General Magruder, dated July 23, 1863. Location: Waco, Texas. Muster Records from Compiled Service Records of Confederate General and Staff Officers, and Non-regimental Enlisted Men. 
Carter, R. G.

1935 On the Border with Mackenzie: or Winning West Texas from the Comanches. Enyon Printing Co., Washington D.C.

Clardy, J. J. Jackson, R. Wright, V. Wright, R. McMillin, W Prugh, D. Henry, C. Price, R. Gadbury, and C. Nash

1991 Lampasas County, Texas: Its History and its People. Walsworth Publishing, Marceline, Missouri.

Cooper, Captain G. W.

1863 Letter from Captain Cooper (37th Texas Cavalry) to Colonel Terrell dated September 2, 1863. Location: Camp near Belton, Bell County, Texas. Muster Record from Compiled Service Records of Confederate General and Staff Officers, and Non-regimental Enlisted Men.

Cullum, G. W.

1920 Biographical Register of the Officers and Graduates of the U.S. Military Academy at West Point, N.Y. 3rd edition. Seeman \& Peters Printers, Saginaw, Michigan.

Dallas Herald

1872 The Indian Raid into Coleman County. May 25, 1872, Volume 19, No. 37. Dallas, Texas.

Frontier Times (FT)

1926 Lige Bevins and Gang Exterminated. July 1926, Volume 3, No. 10, p. 10. Bandera, Texas.

1927 From Curley Hatcher. February 1927, Volume 4, No. 5, p. 8. Bandera, Texas.

1928 From S. P. Elkins. July 1928, Volume 5, No. 10, p. 407. Bandera, Texas.

Gelo, D. J.

2013 Ethnohistorical and Ethnographic Assessment of Comanche Activity in the Fort Hood Area. Archeological Resource Management Series, Research Report Number 63. United States Army Fort Hood, Fort Hood, Texas.

Georgetown Watchman (GW)

1867 Reported Shooting at Lampasas. August 24, 1867, Volume 1, No. 34. Georgetown, Texas.

1869 From Lampasas. May 8, 1869, Volume 3, No. 10. Georgetown, Texas.

1869 Lampasas. June 5, 1869, Volume 3, No. 14. Georgetown, Texas.

Gillett, J. B.

1976 Six Years with the Texas Rangers: 1875-1881. University of Nebraska Press, Lincoln and London. First published in 1921. 
Henry, G. V.

1873 Military Record of Army and Civilian Appointments in the United States Army, Vol. II. D. Van Nostrand Publisher, New York.

Howell, K. W.

2012 Still the Arena of Civil War: Violence and Turmoil in Reconstruction Texas 1865-1874. University of North Texas Press, Denton.

Intelligencer-Echo (IE)

1874 Texas Items. November 4, 1874, Volume 1, No. 3. Austin, Texas.

Jackson, T. C., N. W. McCaleb, I. Mullins, W. B. Pace, and R. Townsend

1866 Letter From Lampasas Citizens to Senators Burney and Cooley. In The Indian Papers of Texas and the Southwest, 1825-1916, edited by D. H. Winfrey and J. M. Day, pp. 103-104. Texas State Historical Association, Austin.

Kavanagh, T. W.

1996 Comanche Political History. University of Nebraska Press, Lincoln.

McCulloch, Major General H. E.

1864 Letter from Major General McCulloch to Brigadier General J. E. Slaughter, Chief of Staff, dated May 30, 1864. Location: Headquarters Northern Sub-District of Texas, Bonham.

O'Neal, B.

2012 Lampasas 1855-1895: Biography of a Frontier Texas Town. Eakin Press, Waco, Texas.

Otis, G. A.

1871 A Report of Surgical Cases Treated in the Army of the United States from 1865 to 1871. Circular No. 3. War Department Surgeon General's Office, Washington D.C., August 17, 1871.

Government Printing Office, Washington, D.C.

Petition from Citizens of Bell County

1863 Letter From Citizens of Bell County to Major General J. Bankhead Magruder dated September 7, 1863. In United States, Civil War Confederate Papers of Citizens or Businesses, 18611865. National Archives Microfilm Publication, M346, Roll 0479, Number 111.

Richardson, R. N.

1933 The Comanche Barrier to South Plains Settlement. Arthur H. Clark Company, Glendale, California.

Richter, W. L.

1987 The Army in Texas During the Reconstruction: 1865-1870. Texas A\&M University Press, College Station, Texas. 
Smith, T. T.

2000 The Old Army in Texas: A Research Guide to the U.S. Army in Nineteenth Century Texas. Texas State Historical Association, Austin.

The Southern Intelligencer (SI)

1866 Indian Raid. March 15, 1866, Volume 1, No. 37. Austin, Texas.

1866 Higgledy-Piggledy. May 3, 1866, Volume 1, No. 44. Austin, Texas.

Stevens, R. W.

1975 Texas Ranger Indian War Pensions. Nortex Press, Quanah, Texas.

The Weekly Telegraph Newspaper (WT)

1863 Letter from Bonham. November 17, 1863, Volume 29, No. 34. Houston, Texas.

1863 Condensed Correspondence. December 1, 1863, Volume 29, No. 36. Houston.

Williams, F. C.

1930-1934 Glimpses from the Past: Hamilton County History. As recorded by Mr. Williams in Interviews from 1930-1934. Electronic document, http://freepages.genealogy.rootsweb.ancestry.com/ gazetteer2000/ williams/williams.htm, accessed January 1, 2014. 
APPENDIX 1.

SELECTED TRANSCRIBED ENTRIES FROM POST RETURNS

\begin{tabular}{|c|c|c|c|c|c|c|}
\hline Date & Unit & Commander & Enlisted & Officers & Deaths & Record of events \\
\hline $\begin{array}{l}\text { May } \\
1867\end{array}$ & $\begin{array}{l}\text { 26th Infantry, } \\
\text { Co K }\end{array}$ & $\begin{array}{l}2 \text { Lieut } \\
\text { Charles F. } \\
\text { Roe }\end{array}$ & 54 & 1 & - & $\begin{array}{l}\text { Post established May 30, } 1867 \text { per } \\
\text { Special Order No. } 50 .\end{array}$ \\
\hline \multirow[t]{2}{*}{$\begin{array}{l}\text { June } \\
1867\end{array}$} & $\begin{array}{l}\text { 26th Infantry, } \\
\text { Co K }\end{array}$ & $\begin{array}{l}2 \text { Lieut } \\
\text { Charles F. } \\
\text { Roe }\end{array}$ & 53 & 1 & $\begin{array}{l}\text { Pvt Henry } \\
\text { Pearson, } \\
\text { June 4, } \\
\text { Typhoid } \\
\text { fever }\end{array}$ & $\begin{array}{l}\text { A skirmish with citizens occurred at } \\
10 \mathrm{PM} \text { on June 17, in which 2nd Lieut } \\
\text { Roe and } 16 \text { men participated. 1st Sgt } \\
\text { George C Lyon and Pvt Track (sp?? } \\
\text { wounded. The post was reinforced } \\
\text { with one Sgt and } 6 \text { men of the 6th } \\
\text { Cav on } 21 \text { June. }\end{array}$ \\
\hline & $\begin{array}{l}\text { 6th Cavalry, } \\
\text { Detachment }\end{array}$ & & 7 & - & - & - \\
\hline \multirow[t]{2}{*}{$\begin{array}{l}\text { July } \\
1867\end{array}$} & $\begin{array}{l}\text { 26th Infantry, } \\
\text { Co K }\end{array}$ & $\begin{array}{l}\text { 2nd Lieut } \\
\text { Charles Roe } \\
\text { (end July 6, } \\
\text { 1867) }\end{array}$ & 53 & 1 & - & $\begin{array}{l}\text { Capt and Bvt Lt. Col. AW Evans } \\
\text { assumed command at Post in } \\
\text { compliance with Special Order No. } 81 \\
\text { Hqs Post of Austin June 29, } 1867 . \\
\text { Absent to Austin, Texas in } \\
\text { attendance upon general court } \\
\text { martial. Private Lance McCormick } \\
\text { apprehended from desertion June 29, } \\
1867 \text { near Fort Columbus. Private } \\
\text { Bryant apprehended from desertion } \\
\text { July 13, } 1867 \text { near Lampasas, Texas. } \\
\text { Private Cahill discharged by } \\
\text { Surgeons Certificate of Disability } \\
\text { June 27, } 1867 \text { Austin, Texas. }\end{array}$ \\
\hline & $\begin{array}{l}\text { 6th Cavalry, } \\
\text { Detachment }\end{array}$ & $\begin{array}{l}\text { Capt., Bvt. Lt } \\
\text { Col Andrew W } \\
\text { Evans (started } \\
\text { July } 29,1867 \text { ) }\end{array}$ & 7 & 1 & - & 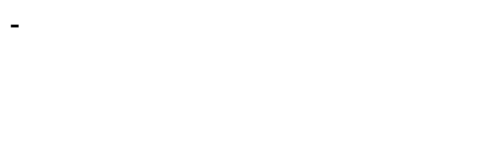 \\
\hline \multirow[t]{2}{*}{$\begin{array}{l}\text { Aug } \\
1867\end{array}$} & $\begin{array}{l}\text { 26th Infantry, } \\
\text { Co K }\end{array}$ & & 53 & - & - & $\begin{array}{l}\text { Private Lance McCormick taken up } \\
\text { from desertion on last post return is } \\
\text { dropped from this one it having been } \\
\text { ascertained that he did not belong to } \\
\text { the } 26 \text { th infantry. Private B Jones, B } \\
\text { Thompson Co B and Co L 6th US } \\
\text { Calvary returned to duty with their } \\
\text { Companies at Austin. 2nd Lieut JA } \\
\text { Richardson } 26 \text { th Infantry in charge of } \\
\text { detachment } 6 \text { Calvary in pursuit of } \\
\text { fugitive from justice, arrived August } \\
31,1867 \text {. }\end{array}$ \\
\hline & $\begin{array}{l}\text { 6th Cavalry, } \\
\text { Co L }\end{array}$ & $\begin{array}{l}\text { Capt, Bvt Lt } \\
\text { Col Andrew W } \\
\text { Evans }\end{array}$ & 8 & 1 & - & - \\
\hline
\end{tabular}




\begin{tabular}{|c|c|c|c|c|c|c|}
\hline Date & Unit & Commander & Enlisted & Officers & Deaths & Record of events \\
\hline \multirow[t]{2}{*}{$\begin{array}{l}\text { Sept } \\
1867\end{array}$} & $\begin{array}{l}\text { 26th Infantry, } \\
\text { Co K }\end{array}$ & $\begin{array}{l}2 \text { Lieut } \\
\text { Charles F Roe }\end{array}$ & 52 & 1 & - & $\begin{array}{l}\text { Capt., Bvt Lt Col. Evans relinquished } \\
\text { command of Post in compliance with } \\
\text { orders from? Office, Sept 6th } 1867 \text {. } \\
\text { Private Daniel Jones Co L 6th US } \\
\text { Calvary died at the Post Sept } 17 \\
1867 \text { from wounds received while in } \\
\text { discharge of duty, August } 17,1867 \\
\text { near Lampasas, Texas. Sgt Daniel } \\
\text { Walker and Pvt Rice L Co 6th Calvary } \\
\text { and Private Goderin B Co 6th Cav } \\
\text { returned to duty with their Companies } \\
\text { at Austin, Texas. }\end{array}$ \\
\hline & $\begin{array}{l}\text { 6th Cavalry, } \\
\text { Detachment }\end{array}$ & - & - & - & $\begin{array}{l}\text { Pvt } \\
\text { Daniel } \\
\text { Jones, } \\
\text { Sept 17, } \\
\text { from } \\
\text { wounds } \\
\text { received } \\
\text { Aug } 17 \text {, } \\
1867\end{array}$ & - \\
\hline $\begin{array}{l}\text { Oct } \\
1867\end{array}$ & $\begin{array}{l}\text { 26th Infantry, } \\
\text { Co K }\end{array}$ & $\begin{array}{l}2 \text { Lieut } \\
\text { Charles F Roe }\end{array}$ & 53 & 1 & - & $\begin{array}{l}\text { Capt William H McLaughlin assigned } \\
\text { to Co. K by SO No. } 101 \mathrm{HQ} 26 \text { th } \\
\text { Infantry Oct } 14,1867 . \text { Absent sick at } \\
\text { York, Penn since Oct } 1867 \text {. }\end{array}$ \\
\hline $\begin{array}{l}\text { Nov } \\
1867\end{array}$ & $\begin{array}{l}\text { 26th Infantry, } \\
\text { Co K }\end{array}$ & $\begin{array}{l}2 \text { Lieut } \\
\text { Charles F Roe }\end{array}$ & 21 & 1 & - & $\begin{array}{l}\text { Garrison reduced to one officer and } \\
\text { twenty men by SO No. } 212 \text {. HQ Dist } \\
\text { of Texas. November } 25,1867 \\
\text { ordering } 20 \text { Co. K } 26 \text { th Inf to Austin, } \\
\text { Texas. }\end{array}$ \\
\hline $\begin{array}{l}\text { Dec } \\
1867\end{array}$ & $\begin{array}{l}\text { 26th Infantry, } \\
\text { Co K }\end{array}$ & $\begin{array}{l}2 \text { Lieut } \\
\text { Charles F Roe }\end{array}$ & 21 & 1 & - & - \\
\hline $\begin{array}{l}\text { Jan } \\
1868\end{array}$ & $\begin{array}{l}\text { 26th Infantry, } \\
\text { Co K }\end{array}$ & $\begin{array}{l}2 \text { Lieut } \\
\text { Charles F Roe }\end{array}$ & 21 & 1 & - & $\begin{array}{l}\text { Post Evacuated per SO No. } 228 \mathrm{HQ} \\
\text { District of Tx, Austin, Texas. Dec 28, } \\
1867 .\end{array}$ \\
\hline $\begin{array}{l}\text { Jan } \\
1868- \\
\text { Apr } \\
1869\end{array}$ & $\begin{array}{l}\text { 36th Infantry, } \\
\text { Co H }\end{array}$ & $\begin{array}{l}1 \text { Lieut, Bvt } \\
\text { Capt. Thomas } \\
\text { Stevens }\end{array}$ & 35 & 2 & $?$ & $\begin{array}{l}\text { May } 1869 \text { Post Returns indicate } 36 \text { th } \\
\text { Inf was at post Before } 4 \text { th Cav took } \\
\text { over on May } 17,1869 \text {. Garrison } \\
\text { personnel numbered } 33 \text { enlisted and } \\
2 \text { officers. Post Returns for } 36 \text { th Inf } \\
\text { are missing or were possibly not } \\
\text { submitted/done by unit. }\end{array}$ \\
\hline
\end{tabular}




\begin{tabular}{llllll}
\hline Date & Unit & Commander & Enlisted & Officers & Deaths \\
\hline May & 4th Cavalry, & Capt. EB & 55 & 2 & - \\
1869 & Co A & Beaumont & & &
\end{tabular}

Record of events

Co. $\mathrm{H}$ 36th Infantry left this Post May

17, 1869. 1st Lt J Murphy US 4th Cav assumed command same date and was relieved by Bvt Lt. COL, Capt. EB Beaumont May 19 1869. The Garrison has been employed in furnishing escorts to the Sheriff and other civil authorities during the month. Lt JH Jones 4th Cav left May 22 with 6 men and $\mathrm{NCO}$ in pursuit of JW Nash (? or J McNash) an absconding Deputy Col. of Res (?) from Burleson Co dated May 25th. Unsuccessful.

$\begin{array}{lllll}\text { June } & \text { 4th Cavalry, } & \text { Capt. EB } & 42 & 5 \\ 1869 & \text { Co A } & \text { Beaumont } & & \end{array}$

Detachment of Company from US 4th Cav Consisting of Eighteen enlisted men under Command of Company Commander (Beaumont) and eight enlisted men of $C_{0}$. B and A US 4th Cav Commanded by 1 Lieut Robert Warren USA Left Post of Lampasas Texas June 17th to Scout for Indians. The detachment marched westward (?) the San Saba was five miles above the town. Approaching 78:W crossed Richland Creek 18 miles from San Saba town. Moving north crossed the Colorado a mile above the mouth of Deep Creek (?). Marched to Camp Colorado (a mile above the mouth of $\mathrm{D}$ ). Arrived at that deserted (???) Post June 21. Left Camp Colorado June 22nd marching north by east crossed Pecan Bayou 6 1/2 from Camp Colorado. Marched 8 (3?) miles from Bayou. Turned south along the mountain through wooded and broken country (or Brown County?) towards Walkers Pass from thence south East passing San Saba to Post of Lampasas. arriving at that place June 27, 1869. Distance marched 203 miles no fresh Indian signs discovered. Water, wood, and grass (?) abundant at all camps. June 28th detachment of $B$ (?) Co 15 enlisted men $B$ and $H($ ?) ? Men under Lt Robert Warren $\mathrm{Co} \mathrm{H}$ (?) accompanied by $2 \mathrm{Lt}$ James $\mathrm{H}$ Jones $\mathrm{Cmd}$ 4th Cav and (?) Surgeon JH Lunning left Post of Lampasas in pursuit of Indians reported to have attacked herders and driven off one hundred horses ten miles from post. This party has not yet returned. 


\begin{tabular}{|c|c|c|c|c|c|c|}
\hline Date & Unit & Commander & Enlisted & Officers & Deaths & Record of events \\
\hline $\begin{array}{l}\text { July } \\
1869\end{array}$ & $\begin{array}{l}\text { 4th Cavalry, } \\
\text { Co A }\end{array}$ & $\begin{array}{l}\text { Capt. EB } \\
\text { Beaumont }\end{array}$ & 32 & 4 & - & $\begin{array}{l}\text { Detachment under Lt Warren } \\
\text { returned to Post July } 31869 \text { after an } \\
\text { unsuccessful scout Distance traveled } \\
200 \text { miles. The garrison has been so } \\
\text { weak that it has been simply been } \\
\text { doing Camp duty. Taking care of } \\
\text { Public animals and property } \\
\text { furnishing occasionally from one to } \\
\text { three men to escort to civil offices and } \\
\text { trains. }\end{array}$ \\
\hline $\begin{array}{l}\text { Aug } \\
1869\end{array}$ & $\begin{array}{l}\text { 4th Cavalry, } \\
\text { Co A }\end{array}$ & $\begin{array}{l}\text { Capt. EB } \\
\text { Beaumont }\end{array}$ & 30 & 5 & - & $\begin{array}{l}\text { The garrison has been employed in } \\
\text { furnishing scouts and details to the } \\
\text { Sheriff and other court authorities } \\
\text { during the past month. }\end{array}$ \\
\hline $\begin{array}{l}\text { Sept } \\
1869\end{array}$ & $\begin{array}{l}\text { 4th Cavalry, } \\
\text { Co A }\end{array}$ & $\begin{array}{l}\text { Capt. EB } \\
\text { Beaumont }\end{array}$ & 29 & 5 & - & $\begin{array}{l}\text { The garrison has been so weak that it } \\
\text { has simply been doing Camp duty } \\
\text { taking care of public animals and } \\
\text { property. Furnishing occasionally } \\
\text { from one to two men as escort to civil } \\
\text { offices and trains. }\end{array}$ \\
\hline $\begin{array}{l}\text { Oct } \\
1869\end{array}$ & $\begin{array}{l}\text { 4th Cavalry, } \\
\text { Co A }\end{array}$ & $\begin{array}{l}\text { Capt. EB } \\
\text { Beaumont }\end{array}$ & 30 & 6 & - & $\begin{array}{l}\text { The garrison has been so weak that it } \\
\text { has simply been employed in } \\
\text { guarding the public property and } \\
\text { occasionally furnishing two or three } \\
\text { men for escorts to offices employed } \\
\text { or civil business. }\end{array}$ \\
\hline $\begin{array}{l}\text { Nov } \\
1869\end{array}$ & $\begin{array}{l}\text { 4th Cavalry, } \\
\text { Co A }\end{array}$ & $\begin{array}{l}\text { Capt. EB } \\
\text { Beaumont }\end{array}$ & 26 & 6 & - & $\begin{array}{l}\text { Nothing worthy of interest transpired. } \\
\text { The company performed the usual } \\
\text { Post duty. }\end{array}$ \\
\hline $\begin{array}{l}\text { Dec } \\
1869\end{array}$ & $\begin{array}{l}\text { 4th Cavalry, } \\
\text { Co A }\end{array}$ & $\begin{array}{l}\text { Capt. EB } \\
\text { Beaumont }\end{array}$ & 21 & 6 & - & $\begin{array}{l}\text { The garrison has been employed in } \\
\text { the usual duties performed at the } \\
\text { Post. Has furnished small escorts of } \\
\text { one and two men to officers on public } \\
\text { duty. }\end{array}$ \\
\hline $\begin{array}{l}\text { Jan } \\
1870\end{array}$ & $\begin{array}{l}\text { 4th Cavalry, } \\
\text { Co A }\end{array}$ & $\begin{array}{l}\text { Capt. EB } \\
\text { Beaumont }\end{array}$ & 38 & 6 & - & $\begin{array}{l}\text { The garrison has been employed in } \\
\text { the usual post duties and has } \\
\text { furnished small details to assist civil } \\
\text { officers in the performance of their } \\
\text { duties. }\end{array}$ \\
\hline $\begin{array}{l}\text { Feb } \\
1870\end{array}$ & $\begin{array}{l}\text { 4th Cavalry, } \\
\text { Co's A, M }\end{array}$ & $\begin{array}{l}\text { Capt. EB } \\
\text { Beaumont } \\
\text { (Co A); Capt. } \\
\text { William } \\
\text { O'Connell (Co } \\
\text { M) }\end{array}$ & 98 & 9 & - & $\begin{array}{l}\text { Company M 4th Cav reinforced this } \\
\text { Post Feb } 11870 \text { Cpt Bvt Major } \\
\text { William O'Connell commanding. The } \\
\text { troops at this post have been } \\
\text { engaged in building stables and } \\
\text { furnishing small escorts to trains and } \\
\text { civil offices. M Co 4th Cav joined this } \\
\text { post Feb } 11870 \text { per SO No. } 4 \mathrm{HQ} \\
\text { military District dated Austin Texas } \\
\text { Jan } 61870 \text { from Post of Austin } \\
\text { Texas. Total strength shown on line } \\
\text { of "Total Regular Garrison" under } \\
\text { head of Gain since last monthly } \\
\text { return. }\end{array}$ \\
\hline
\end{tabular}




\begin{tabular}{|c|c|c|c|c|c|c|}
\hline Date & Unit & Commander & Enlisted & Officers & Deaths & Record of events \\
\hline$?$ & $\begin{array}{l}\text { 4th Cavalry, } \\
\text { Co's A, M }\end{array}$ & $\begin{array}{l}\text { Capt. EB } \\
\text { Beaumont } \\
\text { (Co A); Capt. } \\
\text { William } \\
\text { O'Connell (Co } \\
\text { M) }\end{array}$ & 98 & 9 & - & $\begin{array}{l}\text { Company M US 4th Cav reinforced } \\
\text { this post Feb } 1870 \text {. Capt and Bvt Maj } \\
\text { William O'Connell commanding. The } \\
\text { troops at this post have been } \\
\text { engaged in building stables and } \\
\text { furnishing small escorts to trains and } \\
\text { civil officers. }\end{array}$ \\
\hline $\begin{array}{l}\text { Mar } \\
1870\end{array}$ & $\begin{array}{l}\text { 4th Cavalry, } \\
\text { Co's A, M }\end{array}$ & $\begin{array}{l}\text { Capt. EB } \\
\text { Beaumont } \\
\text { (Co A); Capt. } \\
\text { William } \\
\text { O'Connell (Co } \\
\text { M) }\end{array}$ & 127 & 8 & - & $\begin{array}{l}\text { Bvt Lt Col EB Beaumont Capt 4th } \\
\text { Cav and } 2 \mathrm{Lt} \text { James H Jones 4th US } \\
\text { Cav and } 25 \text { enlisted left this post } \\
\text { March } 141870 \text { on a scout for Indians. } \\
\text { The Detachment proceeded to } \\
\text { Antelope Gap distance } 25 \text { miles and } \\
\text { there encamped five Indians more } \\
\text { seen but camped for want of a } \\
\text { competent guide with the } \\
\text { detachment. The scout returned to } \\
\text { the post March } 191870 \text { for want of } \\
\text { forage after marching a distance of } \\
85 \text { miles. The troops of this command } \\
\text { have been instructed during the past } \\
\text { month in mounted drill and target } \\
\text { practice. }\end{array}$ \\
\hline $\begin{array}{l}\text { Apr } \\
1870\end{array}$ & $\begin{array}{l}\text { 4th Cavalry, } \\
\text { Co's A, M }\end{array}$ & $\begin{array}{l}\text { Capt. EB } \\
\text { Beaumont } \\
\text { (Co A); Capt. } \\
\text { William } \\
\text { O'Connell (Co } \\
\text { M) }\end{array}$ & 124 & 8 & - & $\begin{array}{l}\text { A detachment of } 14 \text { enlisted men } \\
\text { escorted Maj Ferrell Paymaster USA } \\
\text { from this post to the post of Waco } \\
\text { Texas, leaving here April 4th and } \\
\text { returning April } 121870.2 \mathrm{LT} \text { James H } \\
\text { Jones } 4 \text { th US Cav with a detachment } \\
\text { of } 25 \text { enlisted men left this post April } \\
131870 \text { to watch the mountain } \\
\text { passes at Antelope Gaps, Lampasas } \\
\text { County, Texas, with the view of } \\
\text { intercepting bands of hostile Indians. } \\
\text { The detachment was out } 10 \text { days and } \\
\text { returned for want of forage. No } \\
\text { Indians were seen or heard of the } \\
\text { distance marched over } 90 \text { miles. The } \\
\text { Troops at this post have been } \\
\text { instructed during the past month in } \\
\text { target practice and dismounted drill. }\end{array}$ \\
\hline
\end{tabular}




\begin{tabular}{|c|c|c|c|c|c|c|}
\hline Date & Unit & Commander & Enlisted & Officers & Deaths & Record of events \\
\hline $\begin{array}{l}\text { May } \\
1870\end{array}$ & $\begin{array}{l}\text { 4th Cavalry, } \\
\text { Co M }\end{array}$ & $\begin{array}{l}\text { Capt. William } \\
\text { O'Connell }\end{array}$ & 64 & 4 & $\begin{array}{l}2 \text { LT Bvt } \\
\text { Major } \\
\text { William } \\
\text { Russell } \\
\text { died May } \\
15 \text { as a } \\
\text { result of } \\
\text { gunshot } \\
\text { wound } \\
\text { received } \\
\text { May } 14 \text { in } \\
\text { encounter } \\
\text { with } \\
\text { Indians }\end{array}$ & $\begin{array}{l}\text { On the 18th May a small scouting } \\
\text { party consisting of two NCOs and } \\
\text { nine privates from Co M 4th Cav was } \\
\text { sent out under command of } 2 L T \\
\text { William Russell 4th US Cav in pursuit } \\
\text { of Indians who were overtaken on } \\
\text { May } 14 \text { th about } 2 \text { PM when a fight } \\
\text { ensued in which } 2 \text { LT Russell was } \\
\text { mortally wounded and died the next } \\
\text { day. The scout returned to the post } \\
\text { on the } 15 \text { th May having traveled } \\
\text { about } 80 \text { miles. } 2 \text { privates of Co M } \\
\text { 4th Cav were slightly wounded and } \\
\text { one horse killed and } 2 \text { wounded. Co. } \\
\text { A 4th Cav under command of Capt } \\
\text { EB Beaumont left this post on the } \\
\text { 15th May en route to San Antonio } \\
\text { Texas under orders from Dept of HQ. }\end{array}$ \\
\hline $\begin{array}{l}\text { June } \\
1870\end{array}$ & $\begin{array}{l}\text { 4th Cavalry, } \\
\text { Co M }\end{array}$ & $\begin{array}{l}\text { Capt. William } \\
\text { O'Connell }\end{array}$ & 64 & 3 & - & $\begin{array}{l}\text { Post evacuated on the June 16, } \\
\text { 1870. Capt. William O'Connell Post of } \\
\text { Lampasas, Texas to proceed to Fort } \\
\text { Concho, Texas with his command. }\end{array}$ \\
\hline
\end{tabular}

